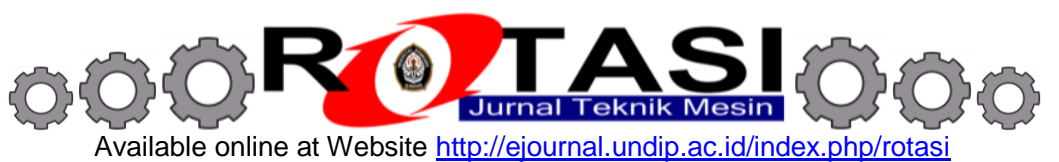

\title{
Perancangan Poros Turbin 5 Mw untuk Pembangkit Listrik Tenaga Panas Bumi
}

\author{
*Achmad Widodo, Kriscahya R.A, Djoeli Satrijo \\ Departemen Teknik Mesin, Fakultas Teknik, Universitas Diponegoro \\ Jl. Prof. Soedarto, SH Tembalang Semarang 50275 Indonesia \\ *E-mail: awid@undip.ac.id
}

\begin{abstract}
Abstrak
Poros turbin merupakan komponen utama turbin uap pada pembangkit listrik tenaga panas bumi yang berperan untuk mentransmisikan daya atau torsi ke poros generator yang terhubung padanya. Poros turbin didesain untuk mampu menerima beban-beban poros saat poros beroperasi fluktuasi daya pada siklus tertentu. Material yang digunakan pada poros adalah stainless steel karena poros bekerja pada kondisi lingkungan korosif. Tujuan penelitian ini adalah untuk menghasilkan desain poros yang memenuhi persyaratan kelayakan desain berupa ASME Code: Design of Transmission Shaft, AS1170.1, ANSI B4.1-1978 dan aman dalam menerima beban statik maupun dinamik. Perangkat lunak yang digunakan untuk memodelkan dan analisis poros adalah Solidworks 2015 dan ANSYS 16. Konsep desain terdiri dari 6 model poros dengan variasi fillet dengan material Stainless Steel jenis AISI 410. Model poros 6 adalah desain poros yang dipilih karena tegangan Von Mises poros 124,49 MPa dengan faktor keamanan statik 2,48 dan tegangan geser maksimumnya senilai 66,01 MPa sudah memenuhi syarat kode ASME. Defleksi poros sebesar 1,3 mm memenuhi persyaratan AS1170.1 dengan ukuran interferensi radial yang digunakan sebesar 0,2 mm sesuai dengan ANSI B4.1-1978. Faktor keamanan lelah (fatigue) poros dari awal operasi sampai overhaul adalah 0,81. Meskipun demikian, diagram S-N menunjukkan bahwa umur poros berdasarkan siklus dari awal operasi sampai overhaul mencapai $2,9 \mathrm{x}$ $10^{5}$ siklus.
\end{abstract}

Kata kunci: poros, turbin uap, stainless steel, torsi, defleksi, fatigue.

\section{Pendahuluan}

Energi panas bumi atau dikenal juga dengan energi geothermal adalah salah satu energi terbarukan yang ramah lingkungan karena menghasilkan emisi gas rumah kaca yang sedikit sekali. Indonesia adalah salah satu negara dengan potensi atau sumber panas bumi yang besar. Secara geografis, Indonesia merupakan negara yang dilintasi oleh jalur gunung berapi. Dari pulau-pulau besar yang ada, hanya pulau Kalimantan yang tidak demikian. Menurut data PT. Pertamina Geothermal Energy, sebanyak $40 \%$ potensi panas bumi dunia dimiliki oleh Indonesia. Sumber-sumber panas bumi tersebut tersebar di 276 lokasi di Sumatera, Jawa, Nusa Tenggara, Maluku, bahkan sampai ke Papua. Tidak heran hal ini membuat Indonesia berada di peringkat ketiga setelah Amerika Serikat dan Filipina dalam pemanfaatan energi panas bumi menjadi sumber pembangkit listrik. Indonesia, dalam kebijakan energi nasional, menargetkan penggunaan energi terbarukan sebesar 23\% pada tahun 2025 dan 31\% pada tahun 2050. Pada tahun 2015, Indonesia baru berhasil memanfaatkan sekitar 5\% dari potensi panas bumi yang dimiliki. Tentu untuk mencapai target tersebut memerlukan proses yang panjang. Pembangunan pembangkit listrik tenaga panas bumi selalu memerlukan pengkajian [1].

Proses pengolahan energi panas bumi menjadi energi listrik adalah melalui beberapa tahap rangkaian. Salah satunya adalah tahap mengalirnya uap hasil pemanasan air oleh panas bumi, yang mengalir menuju ke turbin uap melewati separator supaya menjadi uap kering. Aliran uap kering yang masuk ke turbin uap menyebabkan berputarnya sudu-sudu turbin. Ketika sudu-sudu turbin berputar, poros turbin uap juga ikut berputar karena keduanya adalah komponen yang menyatu. Berputarnya poros turbin uap mengakibatkan berputar pula poros generator pada jumlah putaran tertentu. Di sinilah peran poros turbin uap begitu menentukan, yaitu sebagai komponen yang mentransformasikan energi kinetik uap menjadi energi mekanis, dan mentransmisikan daya atau torsi ke poros generator. Tugas akhir ini akan membahas tentang perancangan desain poros turbin uap beserta indikator-indikatornya yang harus dipertimbangkan dalam proses desain dan perancangan poros.

\section{Modeling}

\subsection{Definisi Elemen}

Poros turbin uap impuls multistage dimodelkan dengan menggunakan elemen tetrahedral dengan ukuran face sizing berukuran $1,3 \mathrm{~mm}$ pada diskontinuitas diameter ataupun fillet dan $10 \mathrm{~mm}$ pada bagian lainnya. Material yang digunakan adalah Stainless Steel jenis AISI 410. Adapun gambaran lengkap dari model yang dibuat pada software ANSYS 16 ditunjukan pada Gambar 1. 


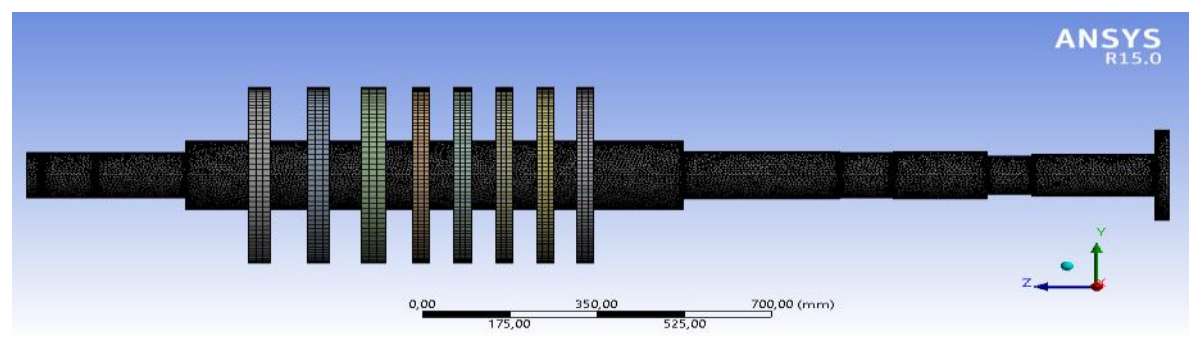

Gambar 1. Modeling pada software ANSYS 16

\subsection{Definisi Material, Geometri dan Beban Poros}

Beban pada poros pada umumnya dibagi menjadi dua jenis, yaitu beban statik dan beban lelah. Beban statik antara lain berupa beban torsi yaitu beban dengan nilai yang bergantung pada daya yang ditransmisikan oleh poros dan besarnya nilai frekuensi kerja poros $(3000 \mathrm{rpm})$, beban lentur akibat beban sendiri dari poros dan beban akibat putaran disc yang dipasang pada poros yaitu kombinasi beban radial dan tangensial disc serta beban kontak disc dengan poros yang menjaga keduanya untuk selalu berputar bersamaan. Sedangkan beban lelah bersifat fluktuatif dan berulang mengikuti pola siklus tertentu [2]. Selain itu, terdapat juga beban aksial yang berasal dari dorongan uap yang mengalir melewati poros [3]. Pada kali ini variabel yang akan dianalisis adalah diameter, nilai tegangan statik, perbandingan frekuensi pribadi dengan frekuensi kerja poros, defleksi, tegangan lelah dan prediksi umur siklus yang diakibatkannya. ASME Code [4]: Design of Transmission Shaft yang menjadi acuan utama dalam desain poros ini, menyatakan bahwa nilai tegangan geser maksimum atau $\tau_{\max }$ poros tidak boleh melebihi $18 \%$ dari ultimate tensile strength atau $30 \%$ dari yield strength material poros, diambil nilai yang terkecil. Material yang digunakan adalah Stainless Steel jenis AISI 410 dengan spesifikasi material sebagai berikut.

Tabel 1. Informasi dari Material Poros

\begin{tabular}{|c|c|c|}
\hline Jenis Material & AISI 410 & Keterangan \\
\hline Densitas $\left(\mathrm{kg} / \mathrm{m}^{3}\right)$ & 7700 & \multirow{6}{*}{ Spesifikasi material poros } \\
\hline Ultimate Tensile Strength $(\mathrm{MPa})$ & 517 & \\
\hline Yield Strength $(\mathrm{MPa})$ & 310 & \\
\hline Modulus Elastisitas $(\mathrm{GPa})$ & 200 & \\
\hline Poisson Ratio & 0,283 & \\
\hline Kekerasan (hardness) Brinell & 154 & \\
\hline Batas maksimum atau $\tau_{\max }$ ASME Code $(\mathrm{MPa})$ & 93 & $30 \%$ dari yield strength AISI 410 \\
\hline Target faktor keamanan statik & 1,66 & Faktor keamanan statik $(\mathrm{SF})=\frac{\mathrm{S}_{\mathrm{sy}}}{\tau_{\max }}$ \\
\hline \multicolumn{2}{|l|}{ Aplikasi umum material } & $\begin{array}{l}\text { Komponen pompa, katup, bagian-bagian turbin uap dan } \\
\text { turbin gas. }\end{array}$ \\
\hline
\end{tabular}

Kemudian, formula torsi elastis digunakan sebagai batasan untuk diameter poros.

$$
\frac{\tau_{\max }}{\mathrm{r}}=\frac{\mathrm{T}}{\mathrm{J}} \text { atau } \tau_{\max }=\frac{16 \mathrm{~T}}{\pi \mathrm{d}^{3}} \text { dengan } \mathrm{P}=\mathrm{T} \cdot \omega=\mathrm{T} \cdot \frac{2 \pi \mathrm{N}}{60}
$$

dimana:

$\begin{array}{llll}\tau_{\max } & =\text { tegangan geser maksimum poros }(\mathrm{Pa}) & \mathrm{P} & =\text { daya poros }(\mathrm{W}) \\ \mathrm{r} & =\operatorname{radius} \text { poros }(\mathrm{m}) & \omega & =\text { kecepatan angular poros }(\mathrm{rad} / \mathrm{s}) \\ \mathrm{J} & =\text { momen polar }\left(\mathrm{m}^{4}\right) & \mathrm{T} & =\text { torsi }(\mathrm{Nm}) \\ \mathrm{T} & =\operatorname{N} & =\text { putaran poros }(\mathrm{rpm}) \\ \mathrm{d} & =\operatorname{diameter}(\mathrm{Nm}) & \mathrm{S}_{\mathrm{sy}} & =\text { shear yield strength sebesar } 0,5 \cdot \text { yield strength }(\mathrm{MPa})\end{array}$

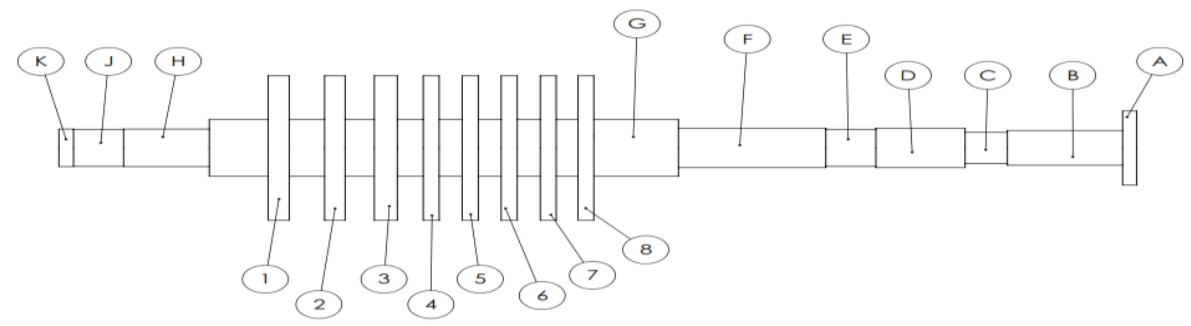

Gambar 2. Bagian-bagian poros turbin uap beserta disc 
Batas ASME Code material dapat digunakan untuk membatasi variasi diameter dari persamaan torsi elastis, sehingga diperoleh batas minimal diameter poros turbin adalah senilai $100 \mathrm{~mm}$. Selanjutnya, geometri poros ditentukan berdasarkan fungsi dari masing-masing bagian poros seperti ditunjukkan pada gambar dan tabel berikut.

Tabel 2. Bagian-bagian poros dan fungsinya

\begin{tabular}{|c|c|c|c|c|}
\hline No & $\begin{array}{l}\text { Nama bagian } \\
\text { poros }\end{array}$ & $\begin{array}{l}\text { Diameter } \\
(\mathrm{mm})\end{array}$ & $\begin{array}{l}\text { Panjang } \\
(\mathrm{mm})\end{array}$ & Fungsi \\
\hline 1 & Part A & 260 & 30 & Sebagai tempat coupling dengan poros generator \\
\hline 2 & Part B & 122 & 245 & Sebagai penghubung part $\mathrm{A}$ dengan part $\mathrm{C}$ \\
\hline 3 & Part $\mathrm{C}$ & 110 & 90 & Sebagai penghubung part $\mathrm{B}$ dengan part $\mathrm{D}$ \\
\hline 4 & Part D & 138 & 189,9 & Sebagai penghubung part $\mathrm{C}$ dengan part $\mathrm{E}$ \\
\hline 5 & Part E & 130 & 106,5 & Sebagai lokasi dipasangnya journal bearing \\
\hline 6 & Part $\mathrm{F}$ & 138 & 313,5 & $\begin{array}{c}\text { Sebagai lokasi dipasangnya labyrinth seal, yaitu saluran labirin } \\
\text { pencegah kebocoran fluida [5] }\end{array}$ \\
\hline 7 & Part $\mathrm{G}$ & 200 & 998 & Sebagai lokasi dipasangnya disc poros turbin \\
\hline 8 & Part $\mathrm{H}$ & 132 & 182,5 & Sebagai lokasi dipasangnya labyrinth seal \\
\hline 9 & Part $\mathbf{J}$ & 130 & 106,5 & Sebagai lokasi dipasangnya journal bearing \\
\hline 10 & Part K & 132 & 31 & Sebagai lokasi dipasangnya thrust bearing \\
\hline 11 & Disc 1 & 508,35 & 45 & \multirow{8}{*}{$\begin{array}{l}\text { Sebagai benda yang dipasangkan pada poros dan lokasi } \\
\text { dipasangnya sudu-sudu turbin atau moving blade }\end{array}$} \\
\hline 12 & Disc 2 & 508,35 & 44 & \\
\hline 13 & Disc 3 & 508,35 & 49 & \\
\hline 14 & Disc 4 & 508,35 & 34 & \\
\hline 15 & Disc 5 & 508,35 & 34 & \\
\hline 16 & Disc 6 & 508,35 & 34 & \\
\hline 17 & Disc 7 & 508,35 & 34 & \\
\hline 18 & Disc 8 & 508,35 & 34 & \\
\hline
\end{tabular}

Tabel 2 menunjukkan bahwa diameter utama poros adalah $200 \mathrm{~mm}$ dan diameter bagian poros yang terkecil adalah $110 \mathrm{~mm}$. Kedua nilai diameter tersebut layak karena sudah melampaui batas minimal diameter yang ditetapkan oleh kode ASME.

Dari data-data di atas, dapat dihitung karakteristik poros berupa volume, massa, berat, dan momen poros sehingga dihasilkan reaksi poros sebesar $\mathrm{R}_{\mathrm{E}}=3961,9 \mathrm{~N}$ dan $\mathrm{R}_{\mathrm{J}}=3588,22 \mathrm{~N}$ pada bagian poros yang merupakan lokasi journal bearing. Variabel berat poros, reaksi pada journal bearing poros dan panjang poros dapat diolah menjadi diagram gaya geser poros dan diagram momen lentur poros yang ditunjukkan pada gambar berikut.

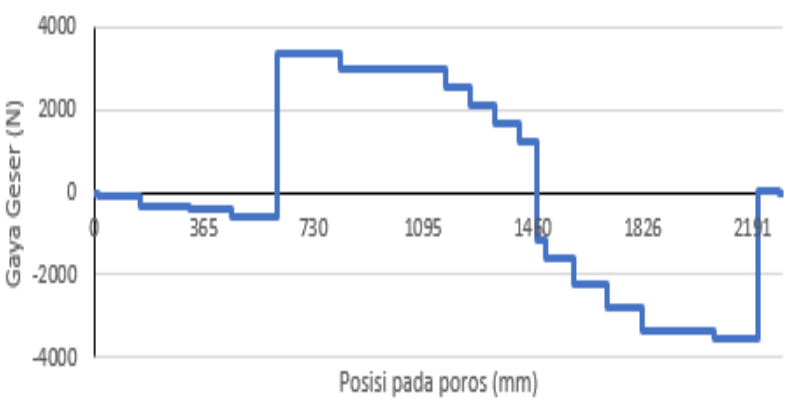

(a)

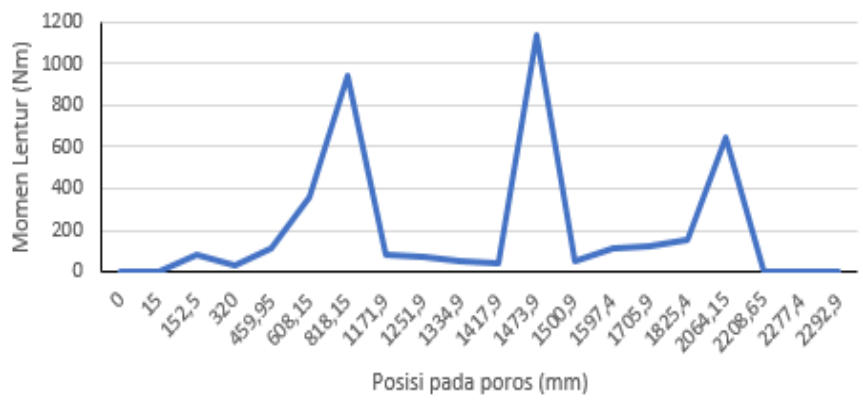

(b)

Gambar 3. (a) Diagram gaya geser poros dan (b) diagram momen lentur poros

Uap masuk ke turbin dikondisikan pada temperatur $210^{\circ} \mathrm{C}$ dalam kondisi saturated vapor, dan keluar dengan tekanan 0,081 bar dalam kondisi saturated vapor pula [6]. Dari interpolasi pada Tabel A-2 [7], diperoleh entalpi pada inlet turbin $\left(\mathrm{h}_{1}\right)$ sebesar $2798,5 \mathrm{~kJ} / \mathrm{kg}$ dan entalpi outlet $\left(\mathrm{h}_{2}\right)$ sebesar $2577 \mathrm{~kJ} / \mathrm{kg}$. Data tersebut digunakan untuk menentukan kecepatan uap dan beban aksial pada turbin dihitung dengan persamaan berikut.

Tabel 3. Perhitungan kecepatan uap dan beban aksial pada turbin

\begin{tabular}{|c|c|c|c|}
\hline $\begin{array}{c}\text { Variabel } \\
(\text { satuan })\end{array}$ & Definisi & Rumus [3] & $\begin{array}{c}\text { Nilai } \\
\text { Variabel }\end{array}$ \\
\hline $\mathrm{c}_{1}(\mathrm{~m} / \mathrm{s})$ & Kecepatan uap inlet turbin & $\mathrm{c}_{1}=\mathrm{c}_{1 \mathrm{t}}=91,5 \cdot \sqrt{\mathrm{h}_{1}-\mathrm{h}_{2}}$ & 1361,78 \\
\hline $\mathrm{u}(\mathrm{m} / \mathrm{s})$ & Kecepatan keliling & $\mathrm{u}=\omega \cdot \mathrm{R}_{\mathrm{disc}}$ & 159,70 \\
\hline
\end{tabular}




\begin{tabular}{|c|c|c|c|}
\hline$\alpha_{1}$ (derajat) & Sudut masuk blade (asumsi) & - & 20 \\
\hline$\omega_{1}(\mathrm{~m} / \mathrm{s})$ & Kecepatan relatif 1 & $\omega_{1}=\sqrt{c_{1}^{2}+u^{2}-2 u c_{1} \cos \alpha_{1}}$ & 1304,78 \\
\hline$\varphi$ & Koefisien resistansi blade & - & 0,95 \\
\hline$\omega_{2}(\mathrm{~m} / \mathrm{s})$ & Kecepatan relatif 2 & $\omega_{2}=\varphi \cdot \omega_{1}$ & 1239,54 \\
\hline$\beta_{1}(\mathrm{~m} / \mathrm{s})$ & Sudut kecepatan & $\sin \beta_{1}=\frac{c_{1}}{\omega_{1}} \cdot \sin \alpha_{1}$ & 72,33 \\
\hline $\mathrm{c}_{2}(\mathrm{~m} / \mathrm{s})$ & Kecepatan uap & $c_{2}=\sqrt{\omega_{2}+u^{2}-2 u \omega_{2} \cos \beta_{1}}$ & 649,27 \\
\hline $\mathrm{R}_{\text {coll }}$ & Dorongan aksial pada collar & $\mathrm{R}_{\text {coll }}=\frac{\pi}{4} \sum_{1}^{\mathrm{k}}\left[\mathrm{d}_{\mathrm{di}}^{2}-\mathrm{d}_{\mathrm{d}(\mathrm{i}-1)}^{2}\right] \mathrm{p}_{\mathrm{i}}+\frac{\pi}{4}\left(\mathrm{~d}_{\mathrm{s} 1}^{2}-\mathrm{d}_{\mathrm{s} 2}^{2}\right) \mathrm{p}_{\mathrm{atm}}$ & \\
\hline $\mathrm{R}_{\mathrm{m}}(\mathrm{N})$ & $\begin{array}{c}\text { Dorongan aksial akibat } \\
\text { momentum uap }(\mathrm{N})\end{array}$ & $\mathrm{R}_{\mathrm{m}}=\frac{\mathrm{G}}{\mathrm{g}}\left(\mathrm{c}_{1}-\mathrm{c}_{2}\right)$ & 49479,81 \\
\hline $\mathrm{R}_{\mathrm{d}}(\mathrm{N})$ & $\begin{array}{l}\text { Dorongan aksial pada } \\
\text { permukaan disc }\end{array}$ & $\mathrm{R}_{\mathrm{d}}=\frac{\pi}{4} \sum_{1}^{\mathrm{z}}\left(\mathrm{d}_{\mathrm{ri}}^{2}-\mathrm{d}_{\mathrm{r}}^{2}\right)\left(\mathrm{p}_{1 \mathrm{i}}-\mathrm{p}_{2 \mathrm{i}}\right)$ & $\begin{array}{l}\text { Lihat } \\
\text { Tabel } 4\end{array}$ \\
\hline $\operatorname{Ro}(\mathrm{N})$ & Total beban aksial & $\mathrm{R}_{\mathrm{o}}=\mathrm{R}_{\mathrm{d}}+\mathrm{R}_{\mathrm{m}}$ & \\
\hline
\end{tabular}

dimana:

$\mathrm{d}_{\mathrm{d}(\mathrm{i}-1)}$ dan $\mathrm{d}_{\mathrm{di}} \quad=$ diameter poros sebelum dan sesudah proyeksi atau penonjolan $(\mathrm{mm})$

$\mathrm{p}_{\mathrm{i}}$ dan $\mathrm{p}_{\mathrm{atm}} \quad=$ tekanan uap pada kamar atau chamber sebelum proyeksi dan tekanan atmosfer $(\mathrm{Pa})$

$\mathrm{k} \quad=$ jumlah proyeksi atau tonjolan diameter pada poros

$\mathrm{d}_{\mathrm{s} 1}$ dan $\mathrm{d}_{\mathrm{s} 2} \quad=$ diameter poros pada bagian labyrinth seal depan dan belakang $(\mathrm{mm})$

$\mathrm{d}_{\mathrm{ri}}$ dan $\mathrm{d}_{\mathrm{r}}$ atau $\mathrm{d}_{\mathrm{rim}}=$ diameter pada lingkar $(\mathrm{rim})$ dan akar $($ root $)$ blade $(\mathrm{mm})$

$\mathrm{p}_{1 \mathrm{i}}$ dan $\mathrm{p}_{2 \mathrm{i}} \quad=$ tekanan uap sebelum dan sesudah melewati stage blade bergerak $(\mathrm{Pa})$

$\mathrm{G} \quad$ = laju massa aliran uap turbin $(\mathrm{kg} / \mathrm{s})$

g

$=$ percepatan gravitasi senilai $9,81 \mathrm{~m} / \mathrm{s}^{2}$

Tabel 4. Hasil Kalkulasi $\mathrm{R}_{\mathrm{d}}$ dan $\mathrm{R}_{\mathrm{o}}$

\begin{tabular}{|l|c|c|c|c|c|c|c|c|}
\hline Stage & 1 & 2 & 3 & 4 & 5 & 6 & 7 & 8 \\
\hline Rd $(\mathrm{N})$ & 15920,22 & 22575,35 & 30773,50 & 40668,96 & 52416,05 & 66169,06 & 82082,29 & 95294,54 \\
\hline Ro $(\mathrm{N})$ & 65400,03 & 72055,16 & 80253,31 & 90148,78 & 101895,86 & 115648,87 & 131562,10 & 144774,36 \\
\hline
\end{tabular}

Pemasangan disc pada poros umumnya dilakukan dengan cara suaian paksa, di mana diameter lubang disc dibuat sedikit lebih kecil daripada diameter poros sehingga terdapat interferensi radial $(\delta)$ seperti yang ditampilkan oleh gambar berikut.

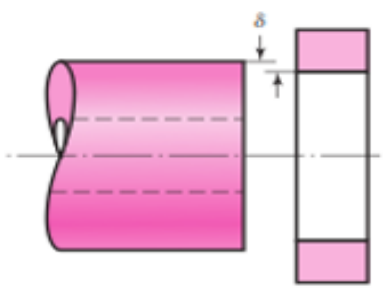

(a)

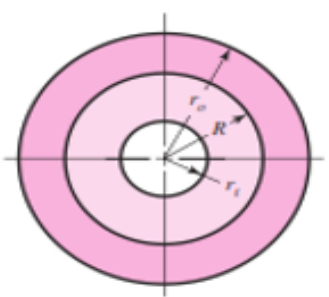

(b)

Gambar 4. Press and shrink fit (a) bagian belum dipasang (b) bagian setelah assembly [2]

Pemasangan suaian paksa dilakukan dengan memasukkan disc ke dalam air atau oli mendidih selama kira-kira satu jam kemudian disc dipasangkan ke poros dengan hydraulic press [3]. Kondisi tersebut (press and shrink fit) mengakibatkan beban berupa tekanan kontak antara disc dan poros yang dihitung dengan persamaan di bawah ini. Berdasarkan ANSI B4.1-1978 FN3 [8], interferensi maksimum yang boleh digunakan pada diameter berukuran 7,87 in atau 200mm adalah senilai 0,0082in atau 0,208mm sehingga beban kontak disc dengan poros diperoleh tekanan kontak p sebesar 1,76 MPa.

$$
\mathrm{p}=\frac{\mathrm{E} \delta}{2 \mathrm{R}^{2}}\left[\frac{\left(\mathrm{r}_{\mathrm{o}}^{2}-\mathrm{R}^{2}\right)\left(\mathrm{R}^{2}-\mathrm{r}_{\mathrm{i}}^{2}\right)}{\left(\mathrm{r}_{\mathrm{o}}^{2}-\mathrm{r}_{\mathrm{i}}^{2}\right)}\right]
$$


dimana:

$\begin{array}{llll}\mathrm{p} & =\text { tekanan kontak }(\mathrm{MPa}) & \mathrm{R} & =\text { radius bagian poros yang dipasang disc } \\ \mathrm{E} & =\text { modulus elastisitas material }(\mathrm{MPa}) & (\mathrm{mm}) & \\ \mathrm{r}_{\mathrm{o}} & =\text { radius dari pusat poros ke titik terluar disc }(\mathrm{mm}) & \delta & =\text { radial interferensi }(\mathrm{mm}) \\ \mathrm{r}_{\mathrm{i}} & =\text { radius rongga/lubang poros }(\mathrm{mm}) & & \end{array}$

Disc yang berputar bersama dengan poros juga menghasilkan tegangan tangensial $\left(\sigma_{\mathrm{t}}\right)$ dan tegangan radial $\left(\sigma_{\mathrm{r}}\right)$ akibat putaran tersebut. Adapun kombinasi tegangan tangensial dan radial maksimum pada disc poros diperoleh adalah senilai 41,49 $\mathrm{MPa}$. Berikut adalah gambar dan rumus untuk menghitung tegangan disc berputar.

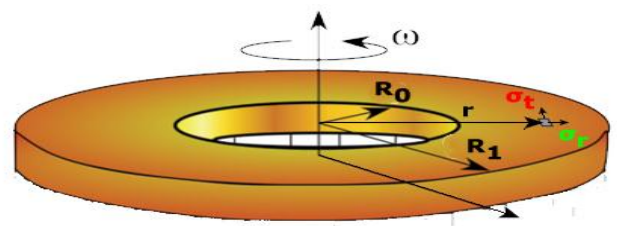

Gambar 5. Tegangan pada disc berputar

$$
\begin{array}{r}
\sigma_{\mathrm{t}}=\rho \cdot \omega^{2}\left(\frac{3+\mathrm{v}}{8}\right)\left(\mathrm{R}_{1}^{2}+\mathrm{R}_{0}^{2}+\frac{\mathrm{R}_{1}^{2} \cdot \mathrm{R}_{0}^{2}}{\mathrm{r}^{2}}-\frac{1+3 \mathrm{v}}{3+\mathrm{v}} \mathrm{r}^{2}\right) \text { dan } \sigma_{\mathrm{r}}=\rho \cdot \omega^{2}\left(\frac{3+\mathrm{v}}{8}\right)\left(\mathrm{R}_{1}^{2}+\mathrm{R}_{0}^{2}-\frac{\mathrm{R}_{1}^{2} \cdot \mathrm{R}_{0}^{2}}{\mathrm{r}^{2}}-\mathrm{r}^{2}\right) \\
\sigma_{\mathrm{t}} \text { dan } \sigma_{\mathrm{r}} \text { dikombinasikan menjadi } \rightarrow \sigma^{\prime}=\sqrt{\sigma_{\mathrm{t}}^{2}-\sigma_{\mathrm{t}} \sigma_{\mathrm{r}}+\sigma_{\mathrm{r}}^{2}}
\end{array}
$$

dimana:

$$
\begin{array}{ll}
\sigma_{\mathrm{t}} & =\text { tegangan tangensial }(\mathrm{MPa}) \\
\sigma_{\mathrm{r}} & =\text { tegangan radial }(\mathrm{MPa}) \\
\rho & =\text { densitas material disc }\left(\mathrm{kg} / \mathrm{m}^{3}\right) \\
\omega & =\text { kecepatan angular disc }(\mathrm{rad} / \mathrm{s})
\end{array}
$$

$$
\begin{array}{ll}
\mathrm{V} & =\text { rasio Poisson material disc } \\
\mathrm{R}_{0} & =\text { radius lubang disc }(\mathrm{m}) \\
\mathrm{R}_{1} & =\text { radius terluar disc }(\mathrm{m}) \\
\mathrm{R} & =\text { radius atau jarak ke elemen tegangan }(\mathrm{m})
\end{array}
$$

Adanya diskontinuitas atau perubahan ukuran diameter bagian-bagian poros menyebabkan terjadinya diskontinuitas distribusi tegangan pada poros. Diskontinuitas diameter tersebut merupakan peningkat tegangan yang bersifat lokal atau stress raiser yang dapat memicu kegagalan pada poros [9]. Pada area-area ini, terdapat konsentrasi tegangan yang ditentukan berdasarkan grafik konsentrasi tegangan baik akibat beban torsi $\left(\mathrm{K}_{\mathrm{ts}}\right)$ ataupun beban lentur $\left(\mathrm{K}_{\mathrm{t}}\right)$ sebagai acuan untuk menentukan daerah mana saja pada poros yang berpotensi menjadi area tegangan maksimum [10].

\section{Hasil dan Pembahasan}

\subsection{Hasil Simulasi Poros}

Data input yang sudah ditentukan pada bagian definisi beban poros dimasukkan sebagai bahan untuk melakukan simulasi tegangan statik poros sehingga bisa diketahui hasilnya berupa tegangan Von Mises maksimum poros, faktor keamanan statik poros, tegangan geser maksimum poros $\left(\tau_{\max }\right)$ dan lokasi di mana tegangan maksimum dihasilkan. Sebelum dilakukan simulasi, sudah ada daerah-daerah yang dicurigai akan terjadi pemusatan tegangan atau tegangan maksimum. Area-area yang dicurigai adalah area 1, 2a, 2b, 3a, 3b dan 4 seperti ditunjukkan oleh gambar berikut.

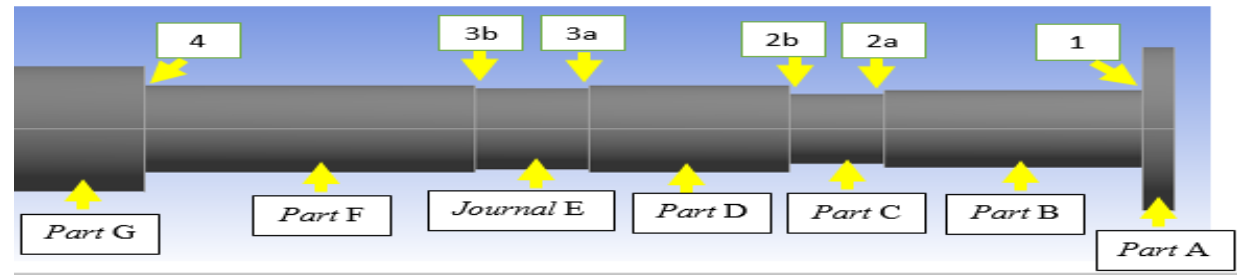

Gambar 6. Daerah kritis poros

Hasil simulasi statik poros ditampilkan pada Tabel 5. Dari hasil simulasi statik poros di atas, tampak bahwa model poros 1 yang tidak memiliki fillet sama sekali mengalami tegangan Von Mises dan tegangan geser melebihi batas yang ditentukan pada area kritis. Pada area kritis tersebut perlu diberikan fillet dengan radius tertentu sebagai solusi untuk mengurangi konsentrasi tegangan area itu. Maka, diperoleh model poros 5 yang memiliki variasi fillet yang sesuai untuk menghasilkan tegangan Von Mises dan tegangan geser maksimum tidak melebihi batas ASME Code dan yield strength. 
Tabel 5. Hasil simulasi statik poros

\begin{tabular}{|c|c|c|c|c|c|c|c|}
\hline $\begin{array}{l}\text { Model } \\
\text { Poros }\end{array}$ & $\begin{array}{c}\text { Material } \\
\text { Poros }\end{array}$ & $\begin{array}{c}\text { Tegangan } \\
\text { Von Mises } \\
\text { maksimum } \\
(\mathrm{MPa})\end{array}$ & $\begin{array}{c}\text { Faktor } \\
\text { Keamanan } \\
\text { Statik }\end{array}$ & $\begin{array}{c}\tau_{\max } \\
(\mathrm{MPa})\end{array}$ & $\begin{array}{c}\text { Batas } \tau_{\max } \\
\text { ASME Code } \\
\text { (MPa) }\end{array}$ & $\begin{array}{l}\text { Lokasi } \\
\text { tegangan } \\
\text { maksimum }\end{array}$ & $\begin{array}{c}\text { Radius fillet sebagai } \\
\text { solusi pada area } \\
\text { tegangan maksimum } \\
(\mathrm{mm})\end{array}$ \\
\hline 1 & \multirow{6}{*}{ AISI 410} & 385,54 & 0,8 & 210,9 & \multirow{6}{*}{93} & $2 b$ & $27,5$ (pada $2 \mathrm{a}$ dan $2 \mathrm{~b})$ \\
\hline 2 & & 292,24 & 1,06 & 156,89 & & 1 & 20 \\
\hline 3 & & 226,96 & 1,36 & 118,12 & & 4 & 20 \\
\hline 4 & & 175,27 & 1,76 & 94,93 & & $3 a$ & 20 (pada 3a dan 3b) \\
\hline 5 & & 124,8 & 2,48 & 66,13 & & $2 b$ & - \\
\hline 6 & & 124,49 & 2,48 & 66,01 & & $2 b$ & - \\
\hline
\end{tabular}

Selanjutnya, model poros 5 perlu dilakukan modal analysis untuk melihat apakah frekuensi pribadi poros aman terhadap defleksi berlebih yang diakibatkan oleh modus getar. Besarnya rasio frekuensi tidak boleh menyentuh angka 1 suapaya tidak terjadi resonansi yang menyebabkan nilai transmission ratio dan defleksi poros berlebih yang mengakibatkan kerusakan poros. Frekuensi pribadi poros, terutama yang nilainya lebih rendah daripada frekuensi kerja poros harus berada pada rasio minimal sebesar $\sqrt{2}$ atau 1,41 untuk operasi yang aman dan halus [11]. Alasannya, nilai frekuensi tersebut sudah pasti dilalui poros ketika poros mulai startup untuk mencapai putaran steady $(\omega)$ sebesar 300rpm atau $50 \mathrm{~Hz}$. Hasil modal analysis ditampilkan oleh tabel di bawah ini.

Tabel 6. Hasil modal analysis poros

\begin{tabular}{|c|c|c|c|c|c|c|c|c|}
\hline $\begin{array}{c}\text { Panjang } \\
\text { Part } \mathrm{F} \\
(\mathrm{mm})\end{array}$ & \multicolumn{4}{|c|}{ Variabel dari $\omega_{\mathrm{n} 1}$} & \multicolumn{4}{c|}{ Variabel dari $\omega_{\mathrm{n} 2}$} \\
\cline { 2 - 10 } & $\begin{array}{c}\omega_{\mathrm{n} 1} \\
(\mathrm{~Hz})\end{array}$ & $\frac{\omega}{\omega_{\mathrm{n} 1}}$ & $\begin{array}{c}\text { Amplitudo } \\
\mathrm{X}\end{array}$ & $\begin{array}{c}\text { Transmission } \\
\text { Ratio }\end{array}$ & $\begin{array}{c}\omega_{\mathrm{n} 1} \\
(\mathrm{~Hz})\end{array}$ & $\begin{array}{c}\omega \\
\omega_{\mathrm{n} 2}\end{array}$ & $\begin{array}{c}\text { Amplitudo X } \\
\text { Transmission } \\
\text { Ratio }\end{array}$ \\
\hline 313,5 & 36,59 & 1,36 & $1,15 \cdot \delta_{s t}$ & 1,15 & 46 & 1,08 & $5,51 \cdot \delta_{s t}$ & 5,51 \\
\hline 310 & 36,85 & 1,36 & $1,18 \cdot \delta_{s t}$ & 1,18 & 55,88 & 0,89 & $5 \cdot \delta_{s t}$ & 5,01 \\
\hline 253,5 & 38,42 & 1,3 & $1,44 \cdot \delta_{s t}$ & 1,44 & 56,67 & 0,87 & $4,33 \cdot \delta_{s t}$ & 4,33 \\
\hline
\end{tabular}

Model awal poros atau model poros 1 sampai dengan model poros 5 tidak dapat memenuhi persyaratan modal analysis seperti yang sudah dinyatakan sehingga perlu untuk dimodifikasi dengan cara diperpendek ukuran panjang bagian poros untuk menambah kekakuannya. Bagian poros yang dikurangi panjangnya adalah part $\mathrm{F}$ (berukuran panjang $313,5 \mathrm{~mm}$ ) karena adanya part $\mathrm{H}$ yang berfungsi sama dengan bagian tersebut yaitu sebagai labyrinth seal. Hasil yang ditampilkan pada tabel menunjukkan bahwa model poros 5 dengan panjang part $\mathrm{F} 253,5 \mathrm{~mm}$ memiliki rasio frekuensi yang sudah sangat mendekati $\sqrt{2}$ untuk frekuensi pribadi di bawah frekuensi kerja pada modus getar pertama, dan frekuensi pribadi yang cukup jauh di atas frekuensi kerja pada modus getar yang lain. Akibatnya, nilai amplitudo yang dihasilkan sudah bisa dikategorikan aman. Model poros yang sudah dikurangi panjangnya tersebut dinamakan model poros 6 .

\subsection{Hasil Simulasi Perbaikan Model Poros}

Hasil tegangan dan faktor keamanan statik pada model poros 6 sudah memenuhi persyaratan dan target keamanan desain. Begitu pula defleksi poros yang tidak melebihi 7,44mm untuk panjang poros 2232,9mm berdasarkan AS 1170.1. Adapun gambar hasil simulasi statik akhir poros adalah sebagai berikut.

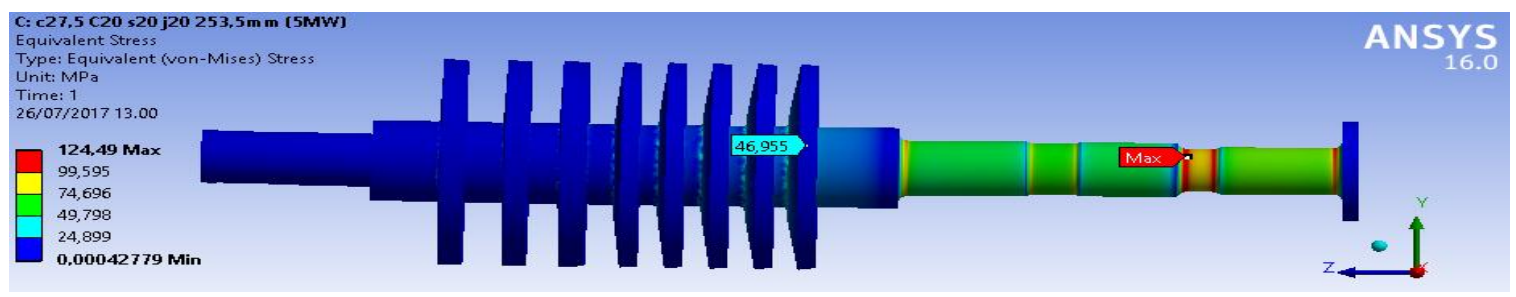

Gambar 7. Hasil simulasi statik perbaikan model poros.

\subsection{Kekuatan Lelah dan Siklus Beban Poros}

Kekuatan lelah material poros yang sudah dikoreksi oleh faktor permukaan, ukuran, pembebanan, temperatur, dan kehandalan yaitu sebesar 59,12 MPa. Kemudian, fluktuasi siklus beban-beban yang dialami poros harus ditentukan. Gambar 8(a) adalah siklus daya harian yang sesuai dengan asumsi penjadwalan daya pada tabel. Sedangkan, Gambar 8(b) adalah siklus daya operasi sampai overhaul, di mana overhaul pada umumnya dilakukan 4 tahun sekali. Alasannya, keausan akibat erosi partikel padat yang melewati poros berpotensi menimbulkan kerusakan yang lebih besar pada 
poros, terutama bagian labyrinth seal setelah melewati jangka waktu tersebut [12]. Garis merah pada gambar grafik menandakan panjangnya 1 siklus pada Gambar 8(b). Sedangkan siklus tegangan lentur akibat berat poros itu sendiri ditampilkan pada Gambar 9 (a).

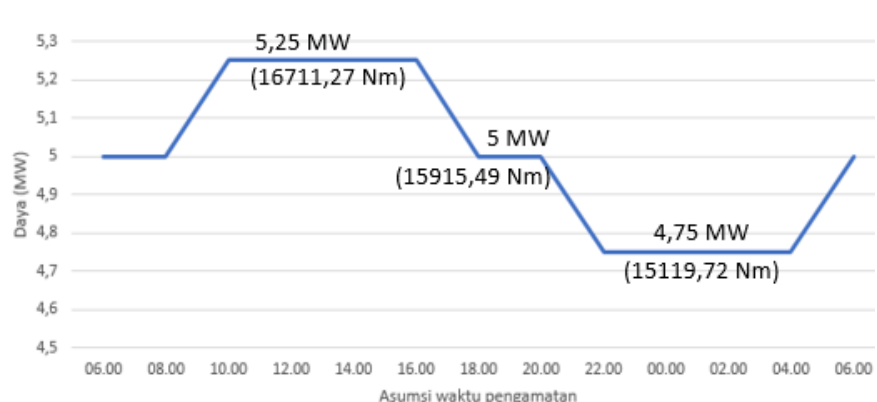

(a)

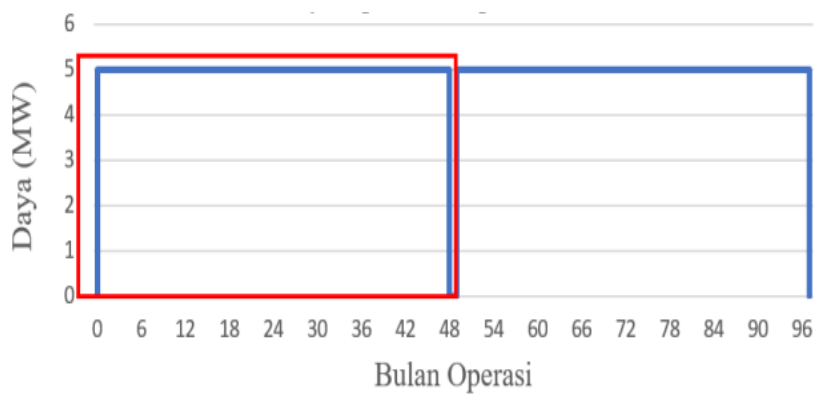

(b)

Gambar 8. (a) Grafik siklus daya harian dan (b) siklus daya opersai sampai overhaul

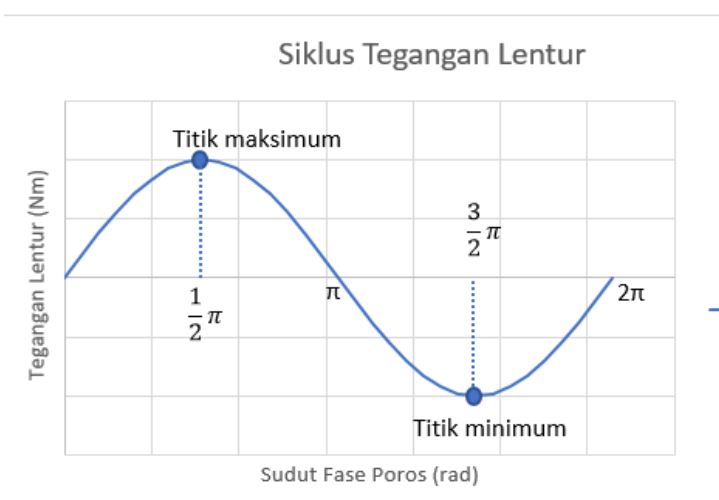

(a)

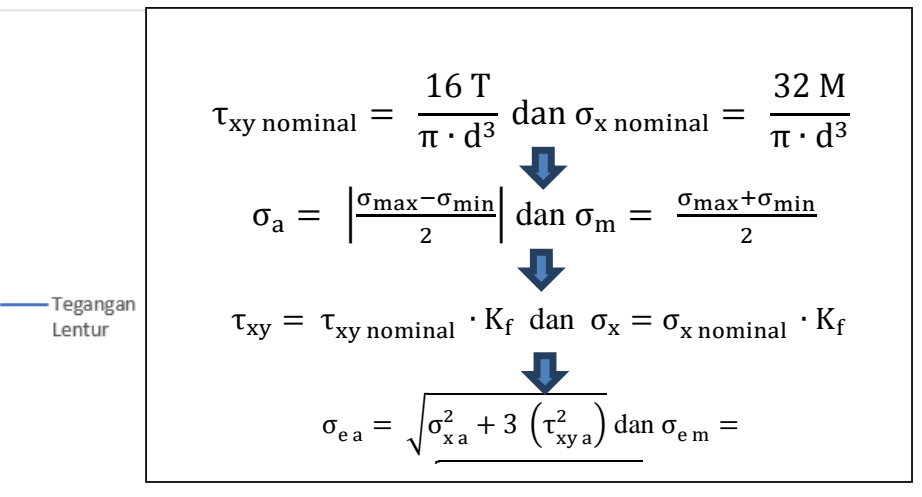

(b)

Gambar 9. (a) Grafik siklus tegangan lentur dan (b)alur hitung tegangan sampai tegangan ekuivalen

Pola siklus pada Gambar 8(a), 8(b) dan 9(a) dijadikan acuan untuk menentukan tegangan yang bekerja pada poros. Tegangan puntir atau torsional nominal poros $\left(\tau_{\mathrm{xy} \text { nominal }}\right.$ atau $\left.\tau_{\mathrm{xy} 0}\right)$ dan tegangan lentur nominal $\left(\sigma_{\mathrm{x} \text { nominal }}\right.$ atau $\left.\sigma_{\mathrm{x} 0}\right)$ adalah awal dari alur hitung tegangan. Lalu, tegangan alternate $\left(\sigma_{\mathrm{a}}\right)$ dan tegangan midrange $\left(\sigma_{\mathrm{m}}\right)$ ditentukan dari nilai tegangan maksimum dan minimum dari beban torsi dan beban lentur berdasarkan pola siklus yang sudah ditampilkan oleh Gambar 8(a), 8(b) dan 9(a). Kemudian, tegangan tersebut perlu dikalikan dengan faktor kelelahan (K $\mathrm{K}_{\mathrm{f}}$. Selanjutnya, tegangan alternate $\left(\sigma_{\mathrm{a}}\right)$ dan midrange poros $\left(\sigma_{\mathrm{m}}\right)$ yang sudah diperoleh dikombinasikan menjadi tegangan ekuivalen alternate $\left(\sigma_{\text {ea }}\right)$ dan midrange $\left(\sigma_{\text {em }}\right)$.

dimana:

$\begin{array}{llll}\tau_{\mathrm{xy}} & =\text { tegangan puntir atau tegangan torsi }(\mathrm{MPa}) & \mathrm{M} & =\text { Momen lentur }(\mathrm{Nmm}) \\ \sigma_{\mathrm{x}} & =\text { tegangan lentur }(\mathrm{MPa}) & \mathrm{T} & =\text { Torsi }(\mathrm{Nmm}) \\ \mathrm{K}_{\mathrm{f}} & =\text { faktor kelelahan } & \mathrm{d} & =\text { diameter bagian poros }(\mathrm{mm}) \\ \sigma_{\max } & =\text { tegangan maksimum dari siklus }(\mathrm{MPa}) & \sigma_{\mathrm{e}} & =\text { tegangan ekuivalen }(\mathrm{MPa}) \\ \sigma_{\min } & =\text { tegangan minimum dari siklus }(\mathrm{MPa}) & & \end{array}$

\subsection{Kegagalan Lelah Poros}

Perhitungan tegangan ekuivalen yang sudah dilakukan menghasilkan nilai-nilai tegangan ekuivalen midrange $\left(\sigma_{\mathrm{em}}\right)$ dan alternate $\left(\sigma_{\mathrm{ea}}\right)$ yang digunakan sebagai titik-titik koordinat pada diagram Goodman $\left(\sigma_{\mathrm{m}}, \sigma_{\mathrm{a}}\right)$. Untuk siklus daya harian, titik koordinat warna merah beban pada diagram Goodman yang diperoleh dari hasil perhitungan adalah $(124,47 ; 6,25)$ dalam MPa dan titik koordinat warna hitam untuk siklus daya operasi sampai overhaul adalah (65,35 ; 65,35). Kemudian, ditarik garis yang melewati kedua titik koordinat tersebut (dihasilkan garis abu-abu untuk beban siklus daya harian, garis oranye untuk beban siklus daya operasi sampai overhaul dan garis biru sebagai garis yield strength material) sehingga dapat dianalisis posisinya terhadap garis kelelahan yang berwarna kuning. 


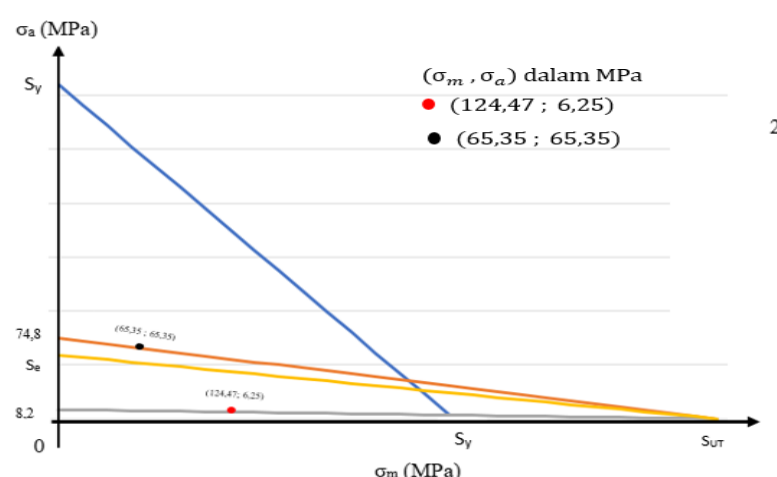

(a)

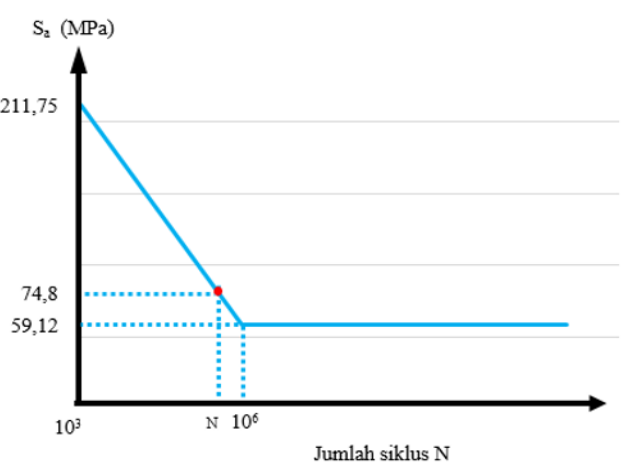

(b)

Gambar 10. (a) Diagram Goodman dan (b) diagram S-N poros

Dari diagram Goodman di atas dapat ditentukan faktor keamanan lelah $\left(\mathrm{n}_{\mathrm{f}}\right)$ sebesar 0,81 dan umur poros menjadi terbatas yaitu 294148 siklus untuk beban siklus dari awal operasi (startup) sampai overhaul.

\section{Kesimpulan}

Setelah dilakukan proses analisis, model poros yang diplih sebagai desain yang paling aman adalah model poros 6 karena telah memenuhi kriteria-kriteria yang diperlukan. Kriteria-kriteria tersebut adalah faktor keamanan statik melebih target senilai 1,66, tegangan geser maksimum tidak melebihi batas yang ditentukan ASME Code untuk material AISI 410 senilai $93 \mathrm{MPa}$, defleksi statis yang dihasilkan tidak melebihi standard AS 1170.1 senilai 7,64mm, rasio frekuensi pribadi dengan frekuensi kerja yang sudah mendekati $\sqrt{2}$ untuk frekuensi pribadi di bawah frekuensi kerja. Adapun faktor keamanan statik poros mencapai 2,48, nilai tegangan geser maksimum poros sebesar 66,01 MPa, defleksi statis poros sebesar 1,3mm, dan rasio frekuensi pribadi dengan frekuensi kerja poros sebesar 1,3. Faktor keamanan lelah poros terendah adalah 0,81 dengan umur poros terbatas sampai 294148 siklus untuk 1 siklus operasi dari awal startup sampai overhaul setara 4 tahun.

\section{Daftar Pustaka}

[1] Pertamina Geothermal Energy, 2015

[2] Budynas-Nisbett. 2006. Shigley's Mechanical Engineering Design, Eighth Edition. New York. U.S.A:McGrawHill Primis.

[3] Shlyakhin, P. 1962. Steam Turbines: Theory and Design. Foreign Languages Publishing House. Moscow.

[4] ASME Code: Design of Transmission Shaft. The American Society of Mechanical Engineers, New York.

[5] Chakravarthy, K.L. 2013. Modeling \& Analysis of Labyrinth Seals Used in Steam Turbines. International Journal of Science and Research (IJSR)

[6] Apriyanto, H. N. 2016. Laporan Kerja Praktek PT.Geodipa Energi: Analisa Penggantian Steam Ejector dengan Kompresor NCG Guna Mengurangi Konsumsi Daya pada NCG Removal System. Semarang: Teknik Mesin Universitas Diponegoro.

[7] Moran M.J, Shaphiro H. N. 2006. Fundamentals of Engineering Thermodynamics $5^{\text {th }}$ Edition. New Jersey. U.S.A: John Willey \& Sons, Inc.

[8] ANSI B4.1-1978: American Standard Limits For Cylindrical Parts. The American Society of Mechanical Engineers, New York.

[9] Babu, R. N. 2008. Determination of Stress Concentration Factors of a Steam Turbine Rotor by FEA. World Academy of Science, Engineering and Technology (WASET)

[10] Spotts, M.F. 1998. Design of Machine Elements $7^{\text {th }}$ Edition. New Jersey, U.S.A:Prentice Hall.

[11] Steidel, Jr. R.F. 1971. An Introduction to Mechanical Vibration $3^{\text {rd }}$ Edition . New York, U.S.A:John Wiley \& Sons, Inc.

[12] Gunnarsson, A. 2013. Maintenance of The Steam Turbines at Hellisheiði Power Plant. Reykjavík, Iceland:Faculty of Industrial Engineering, Mechanical Engineering and Computer, Science University of Iceland. 